\title{
Sensibility in the Relations and Interactions of Teaching and Learning to Be and Do Nursing ${ }^{1}$
}

\author{
Marlene Gomes Terra ${ }^{2}$ \\ Lucia Hisako Takase Gonçalves ${ }^{3}$ \\ Evanguelia Kotzias Atherino dos Santos ${ }^{3}$ \\ Alacoque Lorenzini Erdmann ${ }^{4}$
}

This qualitative study focused on proxemic feelings and feelings of detachment and ambiguity among professors-nurses concerning their experiences. This study aimed to reveal the meanings of sensibility held by being-professor-nurse in teaching and learning to be and do nursing. The theoretical-philosophical support is based on Merleau-Ponty's existential phenomenological approach and the hermeneutics phenomenology of Paul Ricoeur was used. Nineteen professors-nurses from a Higher Education institution in the South of Brazil were interviewed between November and December 2006. Sensibility was revealed as the capacity to observe details in order to intervene in a situation the best way possible, and also as a way to break with exclusive models of the cognitive-instrumental rationality of science and technique, since sensibility is the basis for developing other ways of teaching and learning to be and do Nursing.

Descriptors: Philosophy; Qualitative Research; Education, Nursing.

\footnotetext{
${ }_{1}^{1}$ Paper extracted from Doctoral Dissertation "Significados da sensibilidade para o ser-docente-enfermeiro/a no ensinar e aprender a ser e fazer enfermagem à luz da fenomenologia de Maurice Merleau-Ponty", presented to Universidade Federal de Santa Catarina, $\mathrm{SC}$, Brazil. Supported by PQI/CAPES.

2 Ph.D. in Nursing, Adjunct Professor, Departamento de Enfermagem, Universidade Federal de Santa Maria, RS, Brazil. E-mail: martesm@terra.com.br.

${ }^{3}$ Ph.D. in Nursing, Faculty, Departamento de Enfermagem, Universidade Federal de Santa Catarina, SC, Brazil. E-mail: Itakase@ brturbo.com.br, e-mail: gregos@matrix.com.br.

${ }^{4}$ Ph.D. in Nursing Philosophy, Full Professor, Departamento de Enfermagem, Universidade Federal de Santa Catarina, SC, Brazil. E-mail: alacoque@newsite.com.br.
}

Corresponding Author:

Marlene Gomes Terra

Departamento de Enfermagem. Universidade Fedral de Santa Maria

Av. Roraima, 1000 Cidade Universitária - CCS (prédio 26, $3^{\circ}$ andar)

Bairro: Camobi

CEP: 97105-900 Santa Maria, RS, Brasil

E-mail: martesm@terra.com.br 


\section{Sensibilidade nas relações e interações entre ensinar e aprender a ser e fazer enfermagem}

Esta é uma pesquisa qualitativa, focando os sentimentos de proxemia, de distanciamento e de ambiguidade dos docentes-enfermeiros/as a partir do vivido. O objetivo é revelar os significados da sensibilidade para o ser-docente-enfermeiro/a no ensinar e aprender a ser e fazer Enfermagem. O suporte teórico-filosófico fundamentou-se na abordagem fenomenológica de Maurice Merleau-Ponty e, como recurso metodológico, utilizou-se a hermenêutica-fenomenológica de Paul Ricoeur. Foram entrevistados dezenove docentesenfermeiros/as de uma instituição de ensino superior público do Sul do país, nos meses de novembro e dezembro de 2006. A sensibilidade revelou-se como capacidade de observar os detalhes para intervir numa situação, da melhor forma possível, também como maneira de criar rupturas com modelos exclusivos da racionalidade cognitivoinstrumental da ciência e da técnica, porque é a base para desenvolver outras maneiras de ensinar e aprender a ser e fazer Enfermagem.

Descritores: Filosofia; Pesquisa Qualitativa; Educação em Enfermagem.

\section{La sensibilidad en las relaciones e interacciones entre el enseñar y aprender a ser y el hacer enfermería}

Esta es una investigación cualitativa, enfocando los sentimientos de proxemia, de distanciamiento y de ambigüedad de los docentes enfermeros/as a partir de lo vivido. El objetivo es revelar los significados de la sensibilidad para el ser-docente-enfermero/a en el enseñar y aprender a ser y hacer Enfermería. El soporte teórico filosófico se fundamentó en el abordaje fenomenológico de Maurice Merleau-Ponty y, como recurso metodológico, se utilizó la hermenéutica fenomenológica de Paul Ricoeur. Fueron entrevistados diecinueve docentes enfermeros/as de una institución de enseñanza superior pública del sur del país, en los meses de noviembre y diciembre de 2006. La sensibilidad se reveló como la capacidad de observar los detalles para intervenir en una situación, de la mejor forma posible, también como manera de crear rupturas con modelos exclusivos de racionalidad cognitiva instrumental de la ciencia y de la técnica, porque es la base para desarrollar otras maneras de enseñar y aprender a ser y hacer Enfermería.

Descriptores: Filosofia; Investigación Cualitativa; Educación en Enfermería.

\section{Introduction}

Because teaching and learning to be and do nursing is a human and also inter-subjective relation, it is part of the being-professor-nurse's singularity, which therefore, allows other ways of teaching to be uncovered.

Reflecting about the context experienced by the being-professor-nurse in view of the complexity of activities in Nursing Undergraduate Programs, we perceived the time and effort spent within technical rationality to the detriment of aesthetic rationality. Technical rationality is related to the traditional pedagogical conception, which is focused on curricula where content is isolated, hierarchical and disconnected from reality and is focused on the professor. Aesthetic rationality, on the other hand, is linked to the critical pedagogical concept, which is based on interactive actions and relations between professors and students. Content is based on the reality into which the student is inserted; the focus is not on the professor and the student is considered the subject of learning. Thus, the training of students starts to refer to human phenomena(1).

This topic has been emphasized by several scholars committed to and concerned with the changes 
directed at the nursing field, which have (re)evaluated and signaled, through its posture, the desire for a new epistemology, a return to sensibility. These signs of potential changes can be observed in two recent studies $^{(2-3)}$, where authors highlight the focus that need to be given to teaching.

The first study reveals that the teaching of nursing undergraduate programs in Brazil is traditionally focused on technical issues and studies of the physical procedures related to disease. Consequently, interpersonal relationships, the attention given to human feelings as well as the responsibility to care, became a great challenge because these issues are not valued as they should be ${ }^{(2)}$. The second study shows that despite changes in Brazilian nursing curricula, none of them has promoted a significant change in the practice of professionals(3). The authors perceived that the pedagogical tendencies have been based on the traditional model of education and stress the need for studies directed to the reality experienced in the professors' daily practice.

The perceptions reported by these authors is in line with the experience of the authors of this study as professors, because we observe that education is still based on technical rationality. While reflecting on these situations, we observed that teaching can be different, that is, it can lead to the need to try to do it in a different way, basing teaching on what the being-professornurse thinks and feels about the sensibility of teaching and learning to do nursing. To better understand this phenomenon, we chose to reflect on the reasons nursing undergraduate programs are implementing the curricula required by the National Curricular Guidelines(4).

From this perspective, if one wants to think about teaching and learning to be and do nursing, one needs to dive into the past for a very simple reason: sensibility has millenary roots. It is necessary to awaken it because reflection authorizes one to believe again in living together and on dialog in this world. The rational logical project, conferred onto human intelligence, restricted the freedom to think. Creativity and intuition became controlled by the standards and empirical mechanisms of scientific knowledge. In this way, the human being's sensibility lost two allies: imagination and intuition. These are what allows human beings to be capable to overcome boundaries of the immediate, present and visual. With these the human being achieves the invisible and develops sensibility ${ }^{(5)}$.

The logical and rational models accustomed the human being to observe nature from the perspective of measures. The aesthetic and poetic dimensions were beyond the reach of its gaze. In this sense, only recovering human sensibility will permit the re-encounter of these poetic values. It is necessary to recover imagination and reintegrate intuition as legitimate accesses to reality, because these values constitute human skills to construct knowledge. The reflective attitude turned to the past opens up the hope to re-encounter the poetics of the human being with nature, but this will only happen by the re-structuring of human sensibility ${ }^{(5)}$.

In the course of history, from Greece up to the present, sensibility has had different connotations. It is related to the ability to contemplate, create beauty and harmony through the arts; it is linked to the possibility of, through the senses, obtaining sensible sensations in view of reality; it is related to a way of knowing and is focused on a specifically human quality. In this way, sensibility becomes a profound expression of existence. That is why it is said that those who are moved by the feelings of others are sensitive people(6).

With this notion, the world has meanings other than those attributed by scientific dimensions, because it is necessary to feel the need to recover human beings who are capable of cultivating their passions, instincts and sensibility ${ }^{(7)}$. However it has to occur in two dimensions: as valid knowledge and as affective life, because it is about reconciling reason and sensibility, subjectivity and objectivity $^{(8)}$.

In this sense, this article revealed the meanings concerning sensibility held by the being-professor-nurse in teaching and learning to be and do nursing.

\section{Methodological path}

Because this is a study that involves narratives, actions and expressions of faculty members, we concentrated on the ethical dimension that permeates studies with human subjects according to Resolution no. $196 / 96$ of the National Council of Health ${ }^{(9)}$. The research was approved by the Committee for Research Ethics Concerning Human Subjects at the Federal University of Santa Catarina (protocol no 241/2006).

This is a qualitative study with a phenomenological approach $^{(10)}$ that aimed to highlight aspects of human experience focusing on investigating what is experienced, describing phenomena as they are experienced, attempting to restore the essence in existence ${ }^{(11)}$. In this view, phenomenology is "a philosophy for which the world is always there, before reflection, as an inalienable presence and whose effort is spent to re-discover this naïve contact with the world"(11). 
The study was carried out in the nursing department of a higher education institution in the South of Brazil with 19 professor-nurses, both genders, involved with students attending theoretical and practical courses in all semesters of the nursing undergraduate program and who agreed to participate and signed free and informed consent forms.

An open and individual interview without limitation of time, typical of the phenomenological method, was used to collect the narratives of faculty members. Interviews were recorded from November to December 2006 and the interview was considered an instrument that allowed grasping the experiences of being. Confidentiality of the participants' identities was ensured with the use of the letter $P(P 1, P 2, P 3 . .$.$) because it is the initial of the$ word 'professor'. The number of interviewed professors was not previously determined. Data collection ceased when, through the reading and interpretation of the obtained reports, we realized that the phenomenon is, in its essence, what announces the unveiling of the meaning(12). The interview was initiated with the following guiding question: "what does it mean to you: sensibility to teach and learn to be and do nursing?".

Some information was also obtained through the reading of observations of actions and expressions of interviewers, when these were recorded in a field diary, immediately after the interviews, aiming to directly capture the perceptions of professors' experiences, which enabled the recovery of their bodily emotion, as situations experienced in the past, were projected into the present. For the professors, when they focused on the phenomenon of an experience, it means they "re-learn to look at the world" as if they knew nothing about it(11).

The analysis of the professors' reports included understanding and interpretation according to phenomenology-hermeneutics, because this perspective is based on human beings' experiences, on scientific life and on the reflective life ${ }^{(13)}$. The philosopher seeks the polysemic truth of the phenomenon at levels in which understanding occurs ${ }^{(14)}$ and seeks to clarify the hidden meaning in the apparent meaning of human

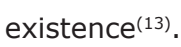

Hermeneutics is a dialoged discourse between the text and its progression, the meaning and the contextual reference of research. It consists in unveiling which message is implicit in the report, which is an event that occurs in time, when someone expresses her/himself while talking in the attempt to describe or represent her/ his world and life. Thus, "it is only viable after delving into semantics, that is, the meaning of words"(15).
Hermeneutics establishes the phrase as the unit of analysis. Thus, one starts "the reading by the phrase followed by the paragraph and then the text as whole. The meaning is composed of units of sentences" (explicative segments of reports, which form a unit of meaning) (15). Distinct entities were entirely examined seeking to explain what the report was saying, underlining ideas that were somewhat linked to the existential theoretical grounding(11). We opted for the referential grounding of the existentialism of Maurice MerleauPonty, who understands the body as a means through which the subject is in the world. The body gives sense and constitutes the subject as being-in-the-world. It is expression, gesture, language; it is nature, culture. This conception of body expresses that it has a relation with the world, an experience of lived world.

\section{Uncovering meanings}

We focused on the thematic category of feelings, which emerged from the written report of professornurses concerning sensibility in the relationships and interactions of teaching and learning to be and do nursing. This category was organized into three subcategories: proxemic feelings, feelings of detachment and feelings of ambiguity, which answered the study's guiding question.

Feelings can sensitize, approximate, distance the professor-nurse in the relationships and interactions with another in the daily routine of teaching and learning to be and do nursing. Professors work from the experienced reality and their experiences are unique. The experienced body is expressive, is the key to sensibility, which is in time and space as a human being. Their experiences are described in the reports and are discussed as follows:

\section{Proxemic feelings}

Proxemics is understood as a social process, relational being, in which individuality is dissolved in the relationships and interactions of professors with another in the teaching and learning to be and do nursing. In this experience, the subject is no longer an individual and becomes a person who plays a role in the theatrical representations of the group in which s/he participates. Thus, it is the relational being of social life with the other and the environment ${ }^{(16)}$, established by the proximity of the daily routine of teaching. Professors assume their function in the environment that allows a union and permits all to express and live their potentialities as beings-on-the-world. It is a meeting that occurs by 
the presence, gesture, dialog, being together through perceptive experience, mediated by the body, that reveals the meanings of that which is spoken and unspoken, which are felt and perceived among professors. Feelings that approximate this were perceived in the reports and are shown as follows:

The supervising training was in the morning. I'd wake up at 5:45am and come back home at 12pm. Not a trace of physical energy, but mentally fulfilled, emotionally very fulfilled, like, of being there with those people, having provided stimuli to students $[. .$.$] we live closer to them \left(\mathrm{P}_{1}\right)$.

The temporality in the report shows the importance to $\mathrm{P}_{1}$ of the circularity of history in the search of comingto-be-in-the-world, which unveiled that emotion and trust in the relationships and interactions that bring together professors and students. Being with people implies presence and attention, when sensibility and personal availability exist. $P_{1}$ draws near to students in an existential attitude that implies opening to knowing and helping the other to be another self(11). From this perspective, $\mathrm{P}_{2}$ reveals that:

You don't put them on your lap and put them on the right place. No, you help them, you support them so they can walk [...] so that students trust you and know your limits [...] (serious look) $\left(P_{2}\right)$.

We perceive that respect, acknowledgement and trust bring others closer. There is another way to teach and learn to do nursing that influences trust in the relation with another. That is why, $\mathrm{P}_{2}$ shows the path to students, so they can delineate their own path, with support. This experience leads the other to express feelings in relation to the other's meaning. Feelings are essential elements in relationships because they are a way to give security to another. With that, the other feels and observes that $\mathrm{s} / \mathrm{he}$ is participating and effectively constructing the process. For that, the professors' dialogs, gestures and actions are essential in relationships and interactions.

In the following report $\mathrm{P}_{3}$ describes how she understands the feelings that approximate the other.

The Experiential Learning group has a very special characteristic that is much more a connection, really, of helping, dialog, to help them to initiate this moment at the university with all these issues. So, it is a very close relationship with the group. [...] I know them very well, I know all their names, where they live, if they are from here or from another place... $\left(\mathrm{P}_{3}\right)$.

The report reveals the dialog that arises from the approximation to the other, and only those who experience this reality know its meaning. There is a feeling of belonging in this approach that unites the collective that is perceived in the report as a gesture.
This is not deliberately offered to the other as something to be assimilated, but the gesture is incorporated as an action of understanding of reciprocity between the professor's intentions and the students' gestures. From this perspective, professors and students are mutually involved in a relationship of intentions and gestures as a possibility of making choices and being another self ${ }^{(11)}$.

The meanings that follow reveal the feelings of $P_{4}$ in relation to the other in the daily practice of nursing with students.

After he got better and got out of mechanical ventilation and he became lucid, another difficulty emerged, which was: how am I going to deal with a person who is in this situation! The students themselves would say it. I noticed it. They would go into the bedroom and get out (serious look). Then I asked them: why did you leave? Ah, professor, I don't know what I'm going to say to him! What are you talking to him? This is the exercise. Going there and changing dressings, change a... this is very easy! Now, the difference is this, c'mon. Let's recover it. (emphasis in her voice) $\left(P_{4}\right)$.

In this narrative, $\mathrm{P}_{4}$ describes an experience with students who were in practical classes caring for a youngster in the intensive care unit. The students' gestures communicated ambiguities of feelings, because in this moment of life they awoke spoken and unspoken feelings. All the time the gestures communicated the suffering from observing the other. In this sense, the professor shows that she perceived the students by their gestures, which are extensions of their bodies. This is the vehicle of being-in-the-world. The body is that which is sensitive, exerts vital communication and the relation with the other and with the world. Professors can only understand the intentionality of students and their attitudes in relation to the other because, through the body, professors make these their own ${ }^{(11)}$.

The professors' actions and expressions are inherent to their world. They are meaningful and plausible in reflection, because growth only occurs if there is an attentive observation of, solidarity and dialog with, the other. Professors contribute to the development of their potentialities, enabling the awakening of students' sensibility. In this way, we understand that teaching and learning to be and do nursing involves intentionality and knowledge as lived experience with the other and as a source of knowledge based on phenomena shared in the care delivery routine.

\section{Feelings of detachment}

Here, some feelings that established detachment in relations with the other in the routine of teaching 
and learning to be and do nursing are presented. The following excerpt is illustrative.

[...] It's hard for me, like, to interact, to have a closer relationship when it is a very large group [...]I think that a smaller group facilitates it. That is why, my relation in practice is much easier (smiles) $\left(P_{5}\right)$.

The spaces of teaching and learning to be and do nursing are those of bodily expression of the professor's being. It calls attention to the fact that the interaction with students only occurs when there is a closer relationship. While the being-professor, as a touching being, has the power to touch and be touched, is capable of touching her/himself, desires to touch, and depends on the touch, desires and does not desire to be touched ${ }^{(11)}$. The expression is a phenomenon that does not depend on what I think about the professor, but of what I can do. What is spoken and unspoken by professors reveals a significant intention in their relations with students. During practical classes, the professors' significant intention, as in the student who re-encounters it, while listening to them, demands spaces of experiences, affections and emotions, so necessary to the structuring of identity and to reinforcing self-esteem ${ }^{(17)}$. When another clarifies his/ her experience, the body is essential, understanding, intersubjectivity acquires a vital dimension in the MerleauPontyan theory of expression. The presence of students through the body, is what signals to the professor their intentions, concrete conditions on which an existential design takes place.

Following is $P_{6}$ 's report, which was accompanied by a smile that revealed her expressions.

The modality was changed this semester, they go for field training and then the substitute professors are those who go with the group to the field. I still find it weird! Because I like when we go to the community with the students. I like the community (smiles) $\left(\mathrm{P}_{6}\right)$.

For professors to existentially share experiences with the other, the teaching and learning to be and do nursing it is necessary to know his/her history in the experienced space ${ }^{(11)}$. The opening to relationships only occurs when there is availability and expression by professors in view of the students' presence. Professors realize that being away from field training with students brings a feeling of strangeness, because they understand the sensibility and responsibility for the education of the future nursing professional.

\section{Feelings of ambiguity}

Ambiguity shows the founding character of language. The meaning emerges from the word, but is not reduced to it, rather it is part of the set of expressions inserted in the body. It is why the word has meaning, but does not contain it. The expression does not exhaust the mystery of what is said, which leads us to observe the unspoken ${ }^{(11)}$.

Following, we present the understanding of professors in their relationships and interactions with the other in the routine of teaching and learning to be and do nursing, related to subjective actions. The sensibility in this study privileges the affective in sociability. It reveals the look on the present, the experienced, the being with. However, it implies acknowledging and respecting the differences in living with the other ${ }^{(16)}$. Professors see themselves and the other as human beings in ambiguity(11). Professors experience feelings of humanity, tenderness, sympathy, compassion, which arise from existential situations inherent to their daily routine. The following report reveals ambiguity, in which we can observe the understanding of sensibility in another way.

It is something that has to be nurtured and pursued (serious look). [...] The issue of humility, of being with, sitting with, of listening, feeling not only with these senses, but it is that thing of the soul, the heart [...] it is getting involved, interacting and having sensibility as a condition to work, the worker who is there. [...] sensibility is: involvement! It is love! Affection! That compassion, it is to have passion with the other. Not that compassion to optimize (smiles) $\left(\mathrm{P}_{7}\right)$.

According to the report of $P_{7}$, sensibility is intersubjective, thus, it depends on opening, interaction and involvement. Sensibility is a process that seeks the contextualization and multidimensionality of the human being to be able to cope and overcome challenges of teaching and learning to be and do nursing beyond the meanings. The professor, as a being-in-the-world needs to co-exist with the other, relate and strengthen feelings. It is in this process that the gap between objectivity and subjectivity is overcome.

\section{Final considerations}

This study enabled us to understand the meanings of sensibility for the being-professor-nurse in teaching and learning to be and do nursing. Phenomenology as a methodological approach proved to be the most appropriate because it made us learn to observe the other and permitted us to walk a path with many discoveries. It helped the realization of questionings and to open our world to new learning. Phenomenologyhermeneutics allows the understanding of meanings that 
the being-professor-nurse attributes to their existence in the nursing world and through their reports, allowed us to achieve the understanding of their interactions with students.

The phenomenon of sensibility for the beingprofessor-nurse is revealed beyond technical rationality. The reports show that teaching and learning to be and do nursing can be based on another dimension, as an exchange between the being-professor and students, which is understood and expressed by sensibility. Therefore, the being-professor provides spaces for objective knowledge without denying spaces for subjective knowledge. Scientific knowledge needs sensitive knowledge.
This study's findings reveal that the understanding of the being-professor concerning the meanings of sensibility is not univocal, as ideas stressed the polysemy of meanings in the set of the hermeneutics of professors' reports. It is necessary that the being-professor-nurse recover sensibility through dialog with the other to teach and learn to be and do nursing. Professors need to mediate situations that involve technical rationality and, in this sense, professors are constantly challenged to transform learning opportunities into experiences meaningful to students based on their own reality, helping them not to merely be executors, but rather encouraging in them the capacity to perceive sensibility, intuition, imagination, and creativity.

\section{References}

1. Santos BS. Pela mão de Alice: o social e o político na pósmodernidade. 9a ed. São Paulo: Cortez; 2003.

2. Camillo So, Silva AL, Nascimento AJ. Percepções do graduando de enfermagem sobre a dimensão humana no seu aprendizado. Rev Latino-am Enfermagem. [online]. 2007, 15(2): 207-13 [citado 2009-05-24], . Disponível em: <http://www.scielo.br/ scielo.php?script $=$ sci_arttext\&pid $=$ S01041169200700020000 $4 \& \mathrm{lng}=\mathrm{pt \& nrm}=\mathrm{iso}>$. ISSN 0104-1169. doi: 10.1590/S010411692007000200004.

3. Pinto JBT, Pepe AM. A formação do enfermeiro: contradições e desafios à prática pedagógica. Rev Latino-am Enfermagem [online]. 2007, 15(1):120-6 [citado 2009-05-24],. Disponível em: <http://www.scielo.br/scielo.php?script=sci_ arttext\&pid=S0104-11692007000100018\&lng=pt\&nrm=iso $>$. ISSN 0104-1169. doi: 10.1590/S0104-11692007000100018.

4. Resolução CNE/CES No 3, de 7 de novembro de 2001. Institui Diretrizes Curriculares do Curso de Graduação em Enfermagem. Diário Oficial da União, Brasília (DF): 9 de Novembro de 2003. Seção $1 ;$ p. 37.

5. Santin S. Educação Física: outros caminhos. $2^{\text {a }}$ ed. Porto Alegre: EST/ESEF; 1993.

6. Abbagnago N. Dicionário de filosofia. $4^{a}$ ed. São Paulo: Martins Fontes; 2003. Sensibilidade; p. 872.

7. Lorenz K. A demolição do homem: crítica à falsa religião do progresso. São Paulo: Brasiliense; 1986.

8. Santin S. Cuidado e/ou conforto: um paradigma para a enfermagem. Texto \& Contexto Enferm. 1998; 7(2):111-32.

9. Ministério da Saúde (BR). Resolução no. 196. Diretrizes e normas técnicas regulamentadoras de pesquisa envolvendo seres humanos. Brasília (DF): MS; 1996.

10. Terra MG. Significados da sensibilidade para o ser-docenteenfermeiro/a no ensinar e aprender a ser e fazer enfermagem à luz da fenomenologia de Maurice Merleau-Ponty. [tese]. Florianópolis (SC): Programa de Pós-Graduação em Enfermagem/ UFSC; 2007.

11. Merleau-Ponty M. Fenomenologia da percepção. $2^{a}$ ed. São Paulo (SP): Martins Fontes; 1999.

12. Boemer MR. A condução de estudos segundo a metodologia de investigação fenomenológica. Rev Latino-am Enfermagem. 1994; 2(1):83-94.

13. Ricoeur P. Interpretação e ideologias. $4^{a}$ ed. Rio de Janeiro: F. Alves; 1990.

14. Ricoeur P. Teoria da interpretação. Rio de Janeiro: Edições $70 ; 1976$

15. Terra MG, Gonçalves LHT, Santos EKA, Erdmann AL. Fenomenologia-hermenêutica de Paul Ricoeur como referencial metodológico numa pesquisa de ensino em enfermagem. Acta Paul Enferm. 2009; 22(1):93-99.

16. Maffesoli M. O tempo das tribos: o declínio do individualismo nas sociedades de massa. $2^{a}$ ed. Rio de Janeiro: Forense Universitária; 1998.

17. Dias FN. Teoria dos Sistemas e Abordagem Centrada na Pessoa: Contributos para uma Recentragem da Comunicação na Relação Pedagógica; 2008 [texto na internet]. 2008 [citado 2008 Ago. 26]. Disponível em: http://www.sociuslogia.com/ artigos/relped01.htm 